\title{
Variability of Agro-morphological Character and Genotype Clustering of Watermelon [Citrullus lanatus (Thunberg) Matsum \& Nakai] as Basic Selection for New Variety
}

\author{
DOI: $10.18196 /$ pt.v10i1.6936
}

\author{
Puji Lestari, Budi Waluyo* \\ Department of Agronomy, Faculty of Agriculture, Universitas Brawijaya Malang, Jalan Veteran Malang, Jawa, Timur, 65145, Indonesia \\ *Corresponding author, email: budiwaluyo@ub.ac.id
}

\begin{abstract}
Watermelon [Citrullus lanatus (Thunb) Matsum \& Nakai] is an important fruit commodity, which has the potential to be developed. Watermelon belongs to the cucurbitaceae family, which has advantages in terms of nutritional, environmental and economic values. Production of watermelon in Indonesia decreased from 2014 to 2016. Therefore, the productivity of watermelons could be increased by conducting this research. The aim of this research was to examine the variability of agro-morphological characters and clustering of watermelon. This research was conducted using seventy eight watermelon genotypes. Seventy-five watermelon genotypes and three commercial varieties were grown in an augmented design. Seventy-five genotypes were spread into four blocks, and each block contained the commercial varieties. The result of this research showed that the cumulative variability reached $81.22 \%$, with seventen main components and only five effective main components. Based on the cluster analysis, the seventy eight watermelon genotypes were divided into seven clusters, resulting in genetic distance of 0.486 - 0.999 and coefficient of similarity of $93 \%$. Ten watermelon genotypes selected based on consumer preferences can be used as recommendations to be released as a variety.
\end{abstract}

Keywords: Character, Clustering, Selection, Variability

\section{ABSTRAK}

Semangka [Citrullus lanatus (Thunb) Matsum \& Nakai] merupakan komoditas buah penting sangat berpotensial untuk dikembangkan. Tanaman semangka yang tergolong dalam famili cucurbitaceae memiliki keunggulan dari segi nilai gizi, lingkungan maupun ekonomi. produksi semangka di Indonesia mengalami fluktuasi, namun dari 2014 ke 2016 produksi semangka di Indonesia pengalami penurunan. Upaya dalam mendukung perakitan varietas yang unggul untuk mendukung produktivitas semangka dengan mengadakan penelitian ini. Tujuan dari penelitian ini untuk mempelajari keragaman karakter agromorfologi dan pengelompokkan tujuh puluh delapan genotipe semangka. Tujuh puluh lima genotipe semangka uji dan tiga varietas komersial ditanam menggunakan rancangan acak kelompok yang diperluas (augmented design). Tujuh puluh lima genotipe tersebar dalam empat blok, setiap blok terdapat masing-masing tiga cek varietas. Hasil penelitian ini menunjukkan nilai keragaman kumulatif 81,22 \% dengan tujuh belas komponen utama dan hanya lima komponen utama yang efektif. Pengelompokkan tujuh puluh delapan genotipe semangka berdasarkan karakter agromorfologi terbagi menjadi tujuh klaster menghasilkan jarak genetik berkisar 0,486 - 0,999 dan koefisien similarity 93 \%. Sepuluh genotipe semangka yang memenuhi preferensi konsumen terseleksi dapat digunakan sebagai rekomendasi untuk dilepas sebagai varietas.

Kata kunci: Karakter, Keragaman, Pengelompokkan, Seleksi

\section{INTRODUCTION}

Watermelon [Citrullus lanatus (Thunb) Matsum also contains beta-carotene and Vitamin A (Naz et $\&$ Nakai] is an important fruit commodity, which has the potential to be developed. Watermelon belongs to the cucurbitaceae family, which has advantages in terms of nutritional, environmental and economic values. Watermelon contains lycopene, which is useful for dealing with stress, cancer, cardiovascular and diabetes. Watermelon fruit lowlands to the highlands, from tropical to subal., 2014). Rind of watermelon acts as a potential source of fiber, and it can reduce the glycemic index. The watermelon skin is usually processed into flour as a basic ingredient of cakes (Naknaen et al., 2016). The adaptation of watermelon can be categorized as good. Watermelons can grow in the

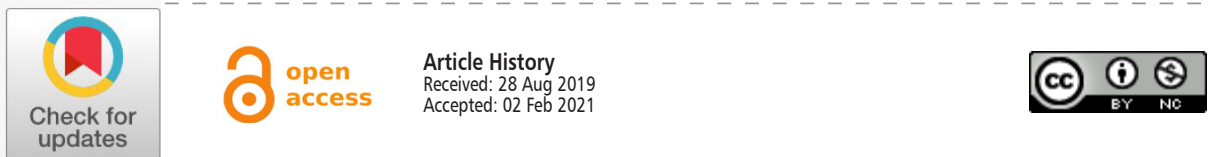


tropical seasons. In sub-tropical areas, watermelons can grow to heights of $1,000 \mathrm{~m}$ above sea level and in tropical areas, watermelons can grow to $1,500 \mathrm{~m}$ above sea level (National Research Council, 2008). In South Africa, precisely in the desert and semidesert areas, watermelon can grow wild (Vavilov, 1951). In terms of economics, watermelon is classified as the beloved fruit for table fruit.

Statistical data of FAO show that the development of watermelon production in Indonesia has fluctuated, but in 2014 to 2016, it decreased by 173,077 tons per ha (FAOSTAT, 2018). The decline in watermelon production may be influenced by environmental and genetic factors (Aragão et al., 2015; Dia et al., 2016). Differentiation of watermelon characteristics based on consumer and farmer preferences are expressed as agro-morphological characters. The visible characters in plants (color and shape) and all quantitative characters related to production that directly contribute to yield (seed size, number of seeds, and time of harvest) are included in agro-morphological characters (Jarvis et al., 2016). The variability of agro-morphological characters and genetic distances are used for the selection of potential genotype to be developed as a variety. The characters of watermelon used as a reference for selection include the visualization of the color of the fruit flesh and the weight of the fruit (Bang et al., 2010; Ilahy et al., 2019).

The information of watermelon genotypes that will be obtained through this research can be used as materials for breeders to develop varieties. Watermelon genotypes obtained from the line or variety being developed are from the Asian, African and European Continents. It is possible that there are variations in the diversity of agro-morphological characters between genotypes of watermelons, in which the more variety and genetic distance between genotypes, the more options available to breeders to assemble varieties. Information on the characteristics of plant traits and methods of breeding in an effort to improve plant traits can be seen through genetic parameters, such as variability of character, heritability and genetic progress (Assefa et al., 2020; Mahla \& Choundhary, 2013).

\section{MATERIALS AND METHODS}

Experimental Design

This research was conducted in January - May 2019 in Seed Bank and Nursery, AgroTechno Park, Academic Business Entity, Brawijaya University, Jatikerto Village, Kromengan District, Malang Regency. Planting materials used in the study were 28 family, consisting of 75 genotypes. Three commercial varieties (Biggie F1, Sunflower F1 and Amor F1) as check genotypes (Table. 1). The watermelon families are the results of the selection of pure lines from various countries by the Laboratory of Plant Breeding, Faculty of Agriculture, Brawijaya University, Malang. Line of [BW] is from Indonesia, [TH] is from Thailand, [VN] is from Vietnam, [TR] is from Turkey, and [LB] is from Libya. Meanwhile, Crimson Sweet is from commercial varieties produced in the United States.

This research was conducted based on an experimental method compiled with an extended randomized group design or augmented design. The seventy five watermelon genotypes were spread in 4 blocks, and each block planted with 3 commercial varieties as check genotypes. The limited number of seeds per genotype and the large number of genotypes are the reasons for using this augmented design (Mramba et al., 2018). Compared to the randomized complete block design, which requires replication of the genotypes tested in each block, in an extended randomized group design or augmented design, replication was only made to the check genotypes (commercial varieties) (Frank et al., 2016). Variability can be controlled, and genotypes efficiently can be assessed through 
Table 1. Genotypes used in the study

\begin{tabular}{|c|c|c|}
\hline No. & Family & Genotypes \\
\hline 1. & Clan[BW]-01 & Clan[BW]-01\#1 \\
\hline 2. & Clan[BW]-02 & Clan[BW]-02\#1 and Clan[BW]-02\#3 \\
\hline 3. & Clan[BW]-03 & Clan[BW]-03\#1 \\
\hline 4. & Clan[BW]-04 & Clan[BW]-04\#1, Clan[BW]-04\#2, Clan[BW]-04\#3 and Clan[BW]-04\#4 \\
\hline 5. & Clan[BW]-05 & Clan[BW]-05\#1, Clan[BW]-05\#3 and Clan[BW]-05\#4 \\
\hline 6. & Clan[BW]-06 & Clan[BW]-06\#1, Clan[BW]-06\#2, Clan[BW]-06\#3 and Clan[BW]-06\#4 \\
\hline 7. & Clan[BW]-07 & Clan[BW]-07\#1, Clan[BW]-07\#2, Clan[BW]-07\#3 and Clan[BW]-07\#4 \\
\hline 8. & Clan[BW]-08 & Clan[BW]-08\#1, Clan[BW]-08\#2, Clan[BW]-08\#3 and Clan[BW]-08\#4 \\
\hline 9. & Clan[BW]-09 & Clan[BW]-09\#2 \\
\hline 10. & Clan[BW]-10 & Clan[BW]-10\#1, Clan[BW]-10\#2, Clan[BW]-10\#3 and Clan[BW]-10\#4 \\
\hline 11. & Clan[BW]-11 & Clan[BW]-11\#1 \\
\hline 12. & Clan[TH]-01 & Clan[TH]-01\#1, Clan[TH]-01\#3 and Clan[TH]-01\#4 \\
\hline 13. & Clan[TH]-02 & Clan[TH]-02\#1, Clan[TH]-02\#2, Clan[TH]-02\#3 and Clan[TH]-02\#4 \\
\hline 14. & Clan[TH]-03 & Clan[TH]-03\#2 and Clan[TH]-03\#3 \\
\hline 15. & Clan[TH]-04 & Clan[TH]-04\#1, Clan[TH]-04\#2 and Clan[TH]-04\#3 \\
\hline 16. & Clan[TH]-05 & Clan[TH]-05\#1 and Clan[TH]-05\#4 \\
\hline 17. & Clan[TH]-06 & Clan[TH]-06\#1, Clan[TH]-06\#2, Clan[TH]-06\#3 and Clan[TH]-06\#4 \\
\hline 18. & Clan[TH]-07 & Clan[TH]-07\#1, Clan[TH]-07\#3 and Clan[TH]-07\#4 \\
\hline 19. & Clan[TH]-08 & Clan[TH]-08\#1, Clan[TH]-08\#2 and Clan[TH]-08\#3 \\
\hline 20. & Clan[TH]-09 & Clan[TH]-09\#1 and Clan[TH]-09\#2 \\
\hline 21. & Clan[TH]-10 & Clan[TH]-10\#1, Clan[TH]-10\#2 and Clan[TH]-10\#3 \\
\hline 22. & Clan[LB]-02 & Clan[LB]-02\#2 and Clan[LB]-02\#4 \\
\hline 23. & Clan[LB]-03 & Clan[LB]-03\#2, Clan[LB]-03\#3 and Clan[LB]-03\#4 \\
\hline 24. & Clan[TR]-01 & Clan[TR]-01\#1 and Clan[TR]-01\#2 \\
\hline 25. & Crimson Sweet & Variety \\
\hline 26. & Clan[VN]-01 & Clan[VN]-01\#1 and Clan[VN]-01\#2 \\
\hline 27. & Clan[VN]-02 & Clan[VN]-02\#1, Clan[VN]-02\#2, Clan[VN]-02\#3 and Clan[VN]-02\#4 \\
\hline 28. & Clan[UB]-01 & Clan[UB]-01\#2, Clan[UB]-01\#3 and Clan[UB]-01\#4 \\
\hline 29. & Biggie F1 & Variety Commercial \\
\hline 30. & SunflowervF1 & Variety Commercial \\
\hline 31. & Amor F1 & Variety Commercial \\
\hline
\end{tabular}

augmented design. New genotypes and varieties are compared in this design. Variety (c) that functions as a replicated check $(r)$ in each trial block and a new genotype (n) were tested one replication in each block (Federer \& Crossa, 2012). Observations were made on 65 agro-morphological characters, consisting of stem, leaf, flower, and fruit characters. Qualitative observations were made using the scoring method, and quantitative data were taken on average.

\section{Statistical Analysis}

The collected data were analyzed using the XLSTAT version 2014.5.03. Meanwhile, the variability of agro-morphological characters was analyzed using Principal Component Analysis (PCA). Percentage of variation to total variability is explained through each component, and a large set of data can be reduced to smaller components that have strong inter-correlations in the set of variables sought (Das et al., 2017). Variations that can be measured using PCA divide total variance into new components. That loading factor and eigenvalue value will determine the variance of a plant character is the reason why PCA analysis is used (Pour-Aboughadareh et al., 2017). Eigenvalue $>1$ determines the main components that affect total variability, and the loading factor $>0.6$ (Guadagnoli \& Velicer, 1988) is used to determine the contributing characters. Meanwhile, the genetic distance was estimated using Agglomerative $\mathrm{Hi}$ erarchical Clustering (AHC) with UPGMA procedure based on similarity values. This analysis of individuals is grouped according to their similarity (Mohammadi \& Prasanna, 2003). 


\section{RESULTS AND DISCUSSION}

Variability of Agro-morphological Characters in Watermelon Genotypes using Principal Component Analysis

Based on the results of PCA analysis with an eigenvalue $>1$, seventeen main components of the agro-morphological characters were obtained. The 17 main components of the agromorphological characters produce a cumulative variability value of $81.22 \%$ (Table 2). Of the seventeen main components, there were only 5 effective (main components) PCs. The value of cumulative variability and eigenvalue decreases with the increasing value of the main component. This also relates to the number of characters that contribute to a component. The first main component (PC1) with a eigenvalue of 9.42 was dominated by the length of the stem, number of leaves, number of male flowers, diameter of the fruit stalks, size of insertion of peduncle, fruit diameter, pericarp thickness, degree of leaf lobing, leaf blistering and strip width. The characters of leaf length, leaf width, fruit length, and seed weight per fruit are the characters that contribute to the variability of $\mathrm{PC} 2$, which has an eigenvalue value of 6.17. In PC3 with the eigenvalue value of 4.64 , the contributing characters were the longitudinal shape of the fruit and the main color of the stripe, while in $\mathrm{PC} 4$, the contributing character was the segment of the first female flower. Eigenvalue of 3.85 places the seed width character as the dominant character in PC5. The cumulative value of $83 \%$ of the contributing characters are fruit weight, \% TSS, flowering period, rasio of fruit length and diameter, and ratio of the number of female flowers and male flowers (Sheng et al., 2012). The number of branches, fruit weight, fruit length, main stem length, fruit skin thickness, \% TSS, and fruit width give a cumulative value of $82.14 \%$ (Said \& Fatiha, 2015). Such results can be seen that each character that produces a variability cumulative value varies. The characters that show varibility depend on the observed genotype population. Most of the characters that showed varibility are fruit weight, fruit length, fruit skin thickness, number of branches, stem length, and $\%$ TSS. Compared with the results of this study, the length of the stem and the thickness of the skin required the most varied characters.

Table 2. Characteristics of potential genotypes for variety release

\begin{tabular}{|c|c|c|c|c|c|c|c|c|}
\hline \multirow[b]{2}{*}{ Genotype } & \multicolumn{8}{|c|}{ Characters } \\
\hline & $\begin{array}{l}\text { Day of } \\
\text { harvesting } \\
\text { (dap) }\end{array}$ & $\begin{array}{l}\text { Weight } \\
\text { of fruit } \\
(\mathrm{kg})\end{array}$ & $\begin{array}{l}\text { Thickness } \\
\text { of pericarp } \\
(\mathrm{mm})\end{array}$ & ${ }^{0}$ Brix & Shape of fruit & $\begin{array}{c}\text { Main color } \\
\text { of flesh } \\
\text { fruit }\end{array}$ & $\begin{array}{l}\text { Main ground } \\
\text { color of skin fruit }\end{array}$ & Cluster \\
\hline Clan[BW]-07\#3 & 64 & 1.42 & 11.25 & 10.65 & medium elliptic & red & Dark green & 1 \\
\hline Clan[BW]-07\#4 & 75 & 0.41 & 4.25 & 9.00 & medium elliptic & red & Dark green & 1 \\
\hline Clan[TH]-09\#2 & 67 & 1.61 & 8.20 & 10.00 & circular & red & $\begin{array}{l}\text { Dark green to very } \\
\text { dark green }\end{array}$ & 2 \\
\hline Clan[TH]-05\#4 & 84 & 0.89 & 9.30 & 10.00 & circular & red & Dark green & 1 \\
\hline Clan[TH]-07\#1 & 78 & 1.47 & 8.65 & 8.90 & medium elliptic & red & $\begin{array}{l}\text { Medium green to } \\
\text { dark green }\end{array}$ & \\
\hline Clan[TH]-08\#2 & 84 & 0.89 & 7.25 & 9.10 & circular & red & $\begin{array}{l}\text { Medium green to } \\
\text { dark green }\end{array}$ & 1 \\
\hline Clan[TH]-10\#1, & 100 & 0.88 & 7.00 & 9.60 & medium elliptic & dark red & Dark green & 1 \\
\hline Clan[VN]-02\#1 & 88 & 1.65 & 7.40 & 8.40 & broad elliptic & yellow & $\begin{array}{l}\text { Dark green to very } \\
\text { dark green }\end{array}$ & 6 \\
\hline Clan[UB]-01\#4 & 78 & 0.88 & 9.72 & 8.90 & medium elliptic & yellow & $\begin{array}{l}\text { Dark green to very } \\
\text { dark green }\end{array}$ & 2 \\
\hline Clan[VN]-02\#4 & 95 & 0.75 & 9.90 & 7.20 & broad elliptic & orange & Medium green & 2 \\
\hline
\end{tabular}


Genetic Distance of Watermelon Genotypes based on Agro-morphological Characters

Seven clusters of watermelon genotypes were produced with a genetic distance of 0.486-0.999 and a similarity coefficient of $93 \%$ (Figure 1). Clusters start from the smallest to the largest number of genotypes. Cluster 4 and cluster 7 fonsist of 1 genotype, while clusters 5 and 6 consist of two genotypes. Meanwhile, cluster 1 consisted 24 genotypes. The position of the largest cluster is in cluster 2 with 43 genotypes. Amor and Biggie, as check genotypes (commercial varieties), have the closest genetic distance, while Clan[LB]-03\#3 with Clan[VN]-02\#3 are genotypes that have the furthest genetic distance. The genotypes from Indonesia, Thailand, Vietnam, Libya and Turkey are spread in each cluster. This means that each cluster is not grouped based on genotypes from the same country. In other words, genotypes from the same family/breed are located in different clusters. This indicates that there are still variations in the characters of a family/line. Similar results occur in previous grouping studies of watermelon genotypes. The clustering was not based on geographical distribution, although the accessions observed were from 7 different countries (Ahou et al., 2016). These variations of character can occur because this study using the phenotypic method (agromorphological characters), resulting in character variations even though they are from the same family/breed. The solution of this case is the need for a molecular methodology to validate the results of phenotypic measurements since the use of molecular methodology is very common in genetic diversity research. Molecular methodology with markers (isozymes, RFLP, AFLP, RAPD, SSR, SRAP, CAPS) is used to detect the genetic variations. SRAP molecular markers are efficient in watermelons that have low genetic diversity (Uluturk et al., 2011).
Watermelon Genotype Selection based on Fruit Characteristics

The characters used as a basis for the selection of genotype include the characteristics that can succeed a variety characterized by attractive fruit features. High yield, shape, weight, skin, flesh, and seeds are considered attractive fruit characteristics. The character component is important, considering that fruits with certain characters will be marketed according to different categories. The appearance of cut fruit is more attarctive if it has a seed color that contrasts with the color of the fruit flesh. Consumers usually swallows the small seeds, while the large seeds will be separated when consumed. Thus, fruits that have small or medium seeds are more commonly found in commercial varieties than fruits with large seeds (Gusmini \& Wehner, 2006). Commercial watermelons in America are divided into several categories. Watermelons that are included in the category of mini-sized fruits have a weight of $<4 \mathrm{~kg}$. Mini watermelon has a great chance to be accepted in the market, because mini watermelon is very practical for consumption to individual consumer. The size of watermelons ranging from $2-3 \mathrm{~kg}$ is currently being developed, targettng families of 1-2 members, especially for young children. The last selection category is based on the color of the stripe pattern on the watermelon skin. The preferred color of stripe pattern on watermelon skin is wide striped pattern with a dark green color (Maynard \& Paris, 2006).

Based on the statement above, it can be seen that consumers want mini-sized fruit characters $(<4 \mathrm{~kg})$ with perfect fruit flesh color, stripes on green fruit skin, high sugar content $\left(\mathrm{Brix}^{\circ}\right)$, and circular or elliptic shape. Fruit that is characterized as whole, dense, fresh appearance, suitable for consumption, and reaching a sufficient level of maturity (minimum $8^{\circ}$ Brix) is a minimum re- 


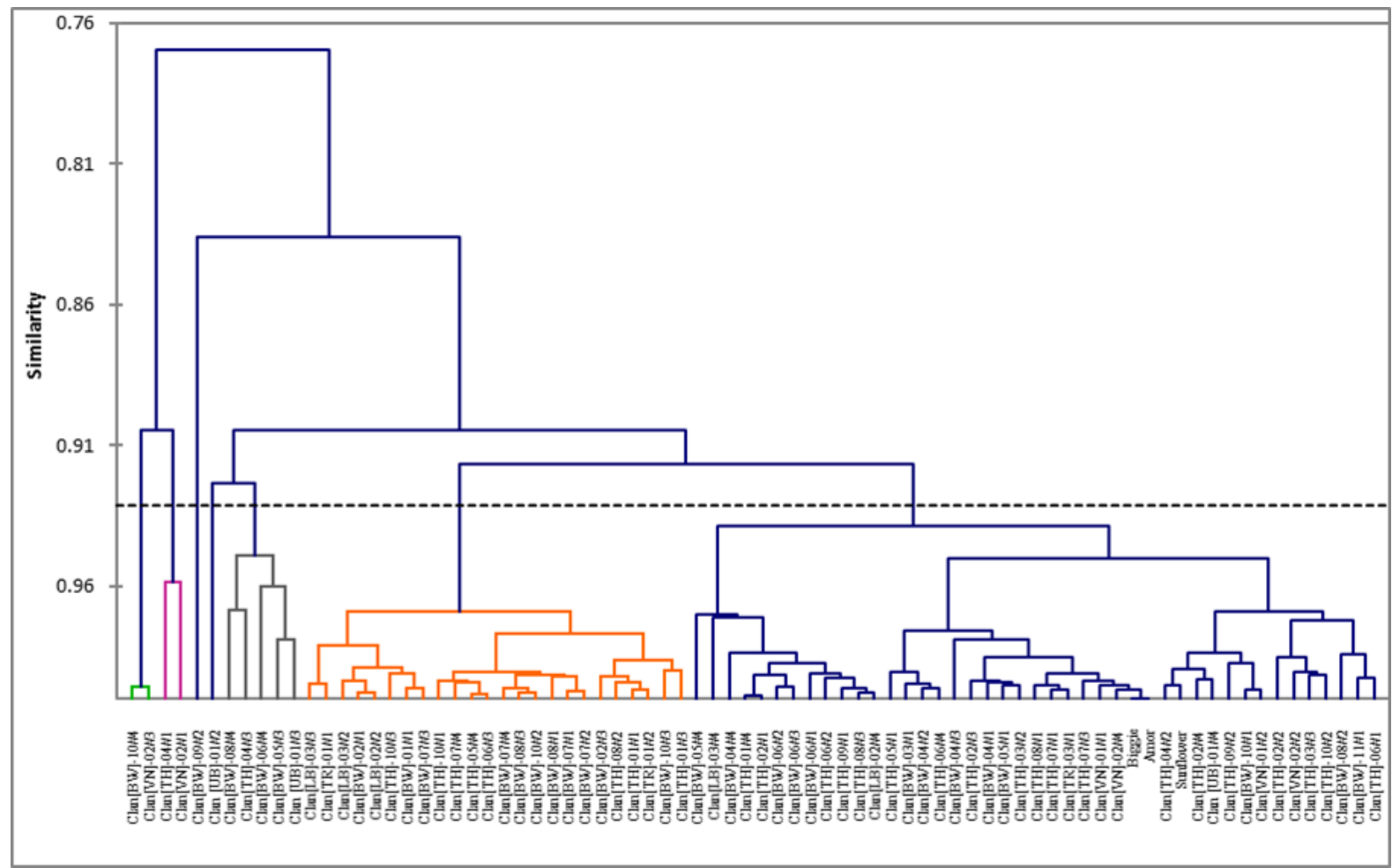

Figure 1. Grouping of seventy-eight watermelons divided into seven clusters based on sixty-five agro-morphological characters
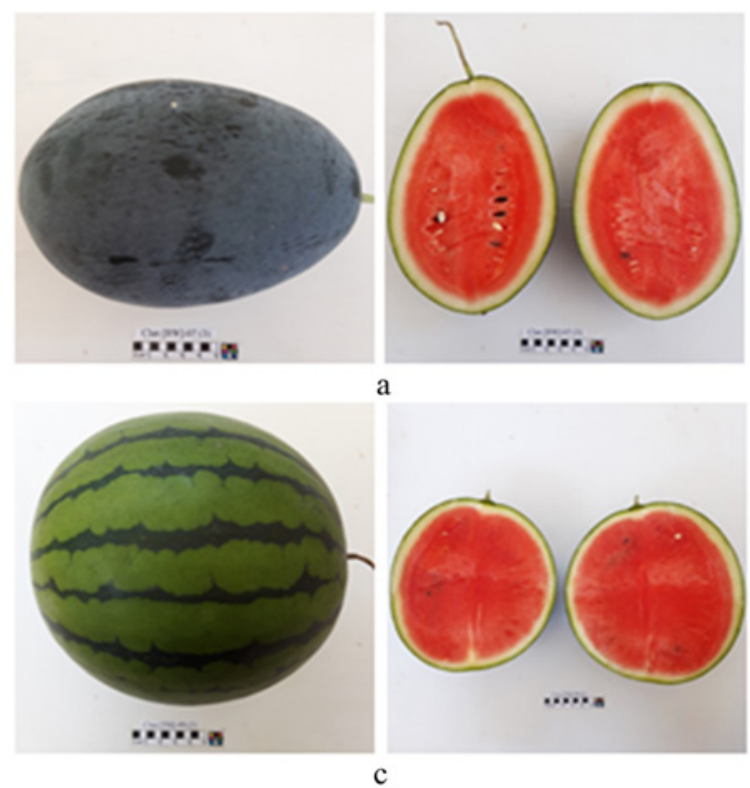
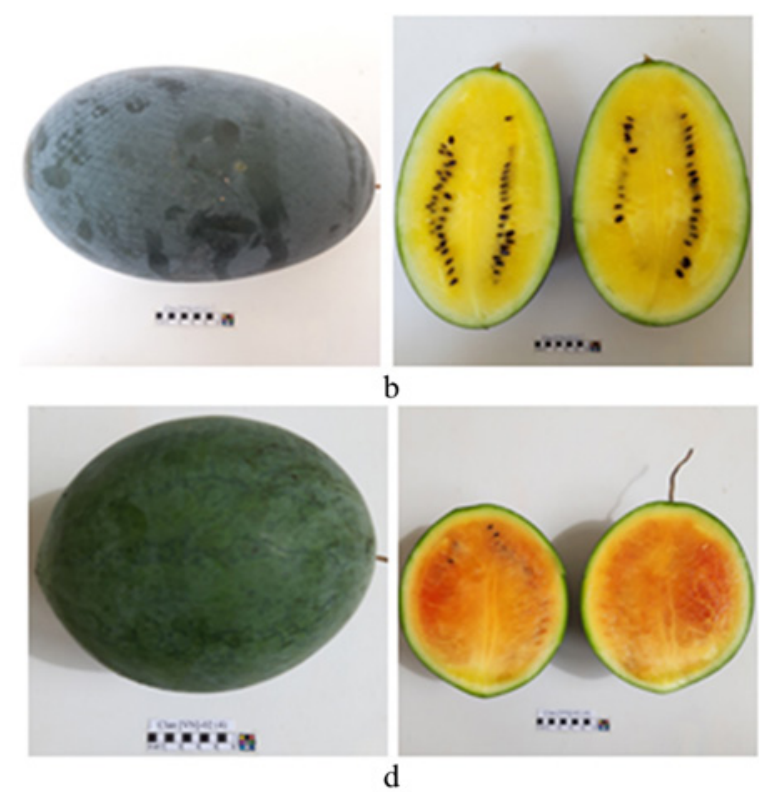

Figure 2. The appearance in fruit characters of watermelon genotypes potential for varieties to be released. Note: a) Clan[TH]-07\#1; b) Clan[VN]-02\#1, c) Clan[TH]-09\#2, d) Clan[VN]-02\# 4 
quirement of the Indonesian National Standard (Badan Standardisasi Nasional, 2009). Watermelon genotypes requiring selection criteria based on consumer preferences are shown in Table 3, and some genotypes showing the appearance of fruit characters are presented in Figure 2. The genotypes include Clan[BW]-07\#3, Clan[BW]-07\#4, Clan[TH]-09\#2, Clan[TH]-05\#4, Clan[TH]-07\#1, Clan[TH]-08\#2, Clan[TH]-10\#1, Clan[VN]-02\#1, Clan[UB]-01\#4, and Clan[VN]-02\#4. The ten selected genotypes varied. Variation of each genotype has a great chance to be released as a variety, which is distributed in clusters 1,2 , and 6 . One of the techniques in multivariate analysis is used to select criteria in selecting elders, namely by measuring genetic distances based on phenotypic characters (Bertan et al., 2005).

\section{CONCLUSION}

The variability of watermelon agro-morphological characters was $81.22 \%$ with 5 effective PCs. Variation of characters varied in stem length, number of leaves, number of male flowers, stem diameter, sticking of fruit handle, fruit diameter, pericarp thickness, degree of leaf curvature, leaf blistering, stripe width, leaf length, leaf width, leaf length, fruit length, seed weight per fruit, longitudinal shape of the fruit, the main color of the strip, the emergence of female flower, and the width of the seeds. The genetic distance of watermelon ranged from 0.486 to 0.999 in 7 clusters. Ten watermelon genotypes that meet consumer preferences are used as variety recommendations.

\section{ACKNOWLEDGEMENTS}

The authors would like to thank the funders of research and facilities of Seed and Nursery Industry, Agro Techno Park, Universitas Brawijaya Academic Business Entity.

\section{REFERENCES}

Ahou, A. G., Kouam eacute, K. K., Nandy, D. F. B., Serge, T. D. B., Hippolyte, H. T., Jean Pierre, B., \& Iri eacute, A. Z. B. (2016). Morphological diversity in oleaginous watermelon (Citrullus mucosospermus) from the Nangui Abrogoua University germplasm collection. African Journal of Biotechnology, 15(21), 917-929. https://doi.org/10.5897/A|B2015.14701

Aragão, F. A. S. de, Nunes, G. H. de S., \& Queiróz, M. A. de. (2015). Genotype $x$ environment interaction of melon families based on fruit quality traits. Crop Breeding and Applied Biotechnology, 15(2), 79-86. https://doi.org/10.1590/198470332015v15n2a15

Assefa, A. D., Hur, O.-S., Ro, N.-Y., Lee, J.-E., Hwang, A.-J., Kim, B.-S., Rhee, J.-H., Yi, J.-Y., Kim, J.-H., Lee, H.-S., Sung, J.-S., Kim, M.-K., \& Noh, J.-J. (2020). Fruit morphology, citrulline, and arginine levels in diverse watermelon (Citrullus lanatus) germplasm collections. Plants, 9(9), 1054. https://doi.org/10.3390/plants9091054

Badan Standardisasi Nasional. (2009). SNI 7420:2009. Standar Nasional Indonesia. Semangka. Badan Standardisasi Nasional.

Bang, H., Davis, A. R., Kim, S., Leskovar, D. I., \& King, S. R. (2010). Flesh color inheritance and gene interactions among canary yellow, pale yellow, and red watermelon. Journal of the American Society for Horticultural Science, 135(4), 362-368. https://doi. org/10.21273/IASHS.135.4.362

Bertan, I., Carvalho, F. I. F. De, \& Oliveira, A. C. De. (2005). Parental selection strategies in plant breeding programs. Journal of Crop Science and Biotechnology, 10(4), 211-222.

Das, S., Das, S. S., Chakraborty, I., Roy, N., Nath, M. K., \& Sarma, D. (2017). Principal component analysis in plant breeding. Biomolecule Reports, September, 1-3.

Dia, M., Wehner, T. C., Perkins-Veazie, P., Hassell, R., Price, D. S., Boyhan, G. E., Olson, S. M., King, S. R., Davis, A. R., Tolla, G. E., Bernier, J., \& Juarez, B. (2016). Stability of fruit quality traits in diverse watermelon cultivars tested in multiple environments. Horticulture Research, 3(1), 16066. https://doi.org/10.1038/ hortres.2016.66

FAOSTAT. (2018). Food and Agriculture Organization Corporate Statistical Database. https://www.fao.org/faostat/en/\#home

Federer, W. T., \& Crossa, J. (2012). I.4 Screening experimental designs for quantitative trait loci, association mapping, genotype-by environment interaction, and other investigations. Frontiers in Physiology, 3(156), 1-8. https://doi.org/10.3389/ fphys.2012.00156

Frank, M. Y., Gaofeng, J., Sylvie, C., Helen, M. B., Scott, D. D., \& Khalid, Y. R. (2016). A method of estimating broad-sense heritability for quantitative traits in the type 2 modified augmented design. Journal of Plant Breeding and Crop Science, 8(11), 257-272. https://doi.org/10.5897//PBCS2016.0614

Guadagnoli, E., \& Velicer, W. F. (1988). Relation of sample size to the stability of component patterns. Psychological Bulletin, 103(2), 265-275. https://doi.org/10.1037/0033-2909.103.2.265

Gusmini, G., \& Wehner, T. C. (2006). Review of watermelon genetics for plant breeders. Cucurbit Genetics Cooperative Report, 61(52-61), 28-29.

Ilahy, R., Tlili, I., Siddiqui, M. W., Hdider, C., \& Lenucci, M. S. (2019). Inside and beyond color: comparative overview of functional 
quality of tomato and watermelon fruits. Frontiers in Plant Science, 10. https://doi.org/10.3389/fpls.2019.00769

Jarvis, D. I., Hodgkin, T., Brown, A. H. D., Tuxill, J., Noriega, I. L., Smale, M., \& Sthapit, B. (2016). Crop Genetic Diversity in the Field and on the Farm. Mary Cady Tew Memorial Fund.

Mahla, H. R., \& Choundhary, B. R. (2013). Genetic diversity in seed purpose watermelon (Citrullus lanatus) genotypes under rainfed situations of Thar Desert. Indian Journal of Agricultural Sciences, 83(3), 300-303.

Maynard, D. N., \& Paris, H. S. (2006). Cucurbitaceae. In The Encyclopedia of Fruit and Nuts (1st ed., pp. 278-282). CABI.

Mohammadi, S. A., \& Prasanna, B. M. (2003). Analysis of genetic diversity in crop plants-salient Statistical Tools and Considerations. Crop Science, 43(4), 1235-1248. https://doi. org/10.2135/cropsci2003.1235

Mramba, L., Peter, G., Whitaker, V., \& Gezan, S. (2018). Generating improved experimental designs with spatially and genetically correlated observations using mixed models. Agronomy, 8(4), 40. https://doi.org/10.3390/agronomy8040040

Naknaen, P., Itthisoponkul, T., Sondee, A., \& Angsombat, N. (2016). Utilization of watermelon rind waste as a potential source of dietary fiber to improve health promoting properties and reduce glycemic index for cookie making. Food Science and Biotechnology, 25(2), 415-424. https://doi.org/10.1007/ s10068-016-0057-z

National Research Council. (2008). Lost crops of Africa. In Volume III : Fruits (pp. 1-165). Yhe National Academies Press.

Naz, A., Butt, M. S., Sultan, M. T., Qayyum, M. M. N., \& Niaz, R. S. (2014). Watermelon lycopene and allied health claims. EXCLI Journal, 13, 650-660. http://www.ncbi.nlm.nih.gov/ pubmed/26417290

Pour-Aboughadareh, A., Ahmadi, J., Mehrabi, A. A., Etminan, A., \& Moghaddam, M. (2017). Assessment of genetic diversity among Iranian Triticum germplasm using agro-morphological traits and start codon targeted (SCoT) markers. Cereal Research Communications, 45(4), 574-586. https://doi. org/10.1556/0806.45.2017.033

Said, E. M., \& Fatiha, H. (2015). Genotypic variation in fruit characters in some genotypes of watermelon cultivated in Morocco. International Journal of Agronomy and Agricultural Research, 6(4), 130-137.

Sheng, Y., Luan, F., Zhang, F., \& Davis, A. R. (2012). Genetic diversity within Chinese watermelon ecotypes compared with germplasm from other countries. Journal of the American Society for Horticultural Science, 137(3), 144-151. https:// doi.org/10.21273/JASHS.137.3.144

Uluturk, Z. I., Frary, A., \& Doganlar, S. (2011). Determination of genetic diversity in watermelon [Citrullus lanatus (Thunb.) Matsum \& Nakai] germaplasm. Autralian Journal of Crop Science, 5(13), 1832-1836.

Vavilov, N. I. (1951). The origin, variation, immunity and breeding of cultivated plants. Chronica Botanica, 13(1/6), 1-387. 